\title{
Autologous or heterologous fibrin sealant scaffold: which is the better choice?
}

\author{
Rui Seabra Ferreira Junior
}

Keywords: Fibrin sealant, Snake venom, Scaffold, Stem cell

\section{Dear Editor-in-chief}

Since the foundation of the Journal of Venomous Animals and Toxins including Tropical Diseases in 1995, special attention has been given to the publication of results from research studies on products developed from animal toxins [1,2]. For years, proteins, enzymes and peptides have been isolated and synthesized in the search for new medications and target molecules. The serine proteases extracted from snake venom were selected as molecules of interest since they act on human and animal hemostatic systems, by the thrombin-like enzymes, converting fibrinogen into fibrin [1,2].

About 20 years ago the researchers of the Center for the Study of Venoms and Venomous Animals (CEVAP) at UNESP proposed to engage in prospecting for a new sealant from a serine protease extracted from the venom of Crotalus durissus terrificus associated with a fibrinogen-rich cryoprecipitate and coagulation factors extracted from buffalos $[1,3,4]$. For medicinal application, this new sealant does not present risk of transmission of infectious diseases, is cheaper on account of being a genuinely Brazilian product, is standardized and was already tested experimentally on rodents (rats and rabbits) and non-rodents (dogs and sheep) [2-5]. In humans, the fibrin sealant was tested in a autologous skin graft of the nasogenian sulcus as donor site to repair a nasal surgical wound, in the immobilization of free periodontal gingival grafts in lower premolars, in the fixation of a conjunctive tissue graft for the correction of gingival marginal tissue recessions and in the treatment of chronic venous ulcers [6-10].

\footnotetext{
Correspondence: rseabra@cevap.unesp.br

Center for the Study of Venoms and Venomous Animals (CEVAP), São Paulo State University (UNESP - Univ Estadual Paulista), Botucatu, São Paulo State, Brazil, Rua José Barbosa de Barros, 1780, Fazenda Experimental Lageado, Botucatu, SP CEP 18.610-307, Brasil
}

\section{() Biomed Central}

(c) 2014 Seabra Ferreira; licensee BioMed Central Ltd. This is an Open Access article distributed under the terms of the Creative Commons Attribution License (http://creativecommons.org/licenses/by/4.0), which permits unrestricted use, distribution, and reproduction in any medium, provided the original work is properly credited. The Creative Commons Public Domain Dedication waiver (http://creativecommons.org/publicdomain/zero/1.0/) applies to the data made available in this article unless otherwise stated.

Recently, we have investigated the effects of the fibrin sealant as a scaffold for mesenchymal stem cells in order to demonstrate the ability of cells to interact with the biological microenvironment [11]. We observed that the product did not affect cell adhesion, proliferation or differentiation and allowed the adherence and growth of mesenchymal stem cells on its surface. Hoechst 33342 and propidium iodide staining demonstrated the viability of mesenchymal stem cells in contact with the fibrin sealant and the ability of the biomaterial to maintain cell survival. We concluded that the new biomaterial is a three-dimensional scaffolding candidate that is capable of maintaining cell survival without interfering with differentiation, and might also be useful in drug delivery. The fibrin sealant has a low production cost, does not transmit infectious diseases from human blood and has properties of a suitable scaffold for stem cells because it permits the preparation of differentiated scaffolds that are suitable for every need.

Similarly, de la Puente et al. [12-14] developed an autologous fibrin scaffold: cheaper, easy to use, natural (with physiological concentrations of fibrinogen), implantable, highly available and with low fibrinogen concentrations. The key point to this model is that no fibrinogen concentration techniques, such as cryoprecipitation or other chemical methods, are used. This system is suitable both for cell culture and cell differentiation. Autologous blood is collected, centrifuged to separate it from the plasma (physiological concentrations in plasma are $2-4 \mathrm{mg} / \mathrm{mL}$ ) and frozen at $-40^{\circ} \mathrm{C}$ until used. Accordingly, more natural and fewer modified fibrins are used and the nature of the fibrin (with its physiological concentrations) is preserved. The authors concluded that the structuring and development of the scaffold is a key point for cell culture because scaffolds of autologous fibrin offer an important alternative due to their low fibrinogen concentrations, which are more suitable for cell growth [12-14]. 
The results of de la Puente et al. [12-14] are in disagreement with those of Gasparotto et al. [11], since the scaffold of the latter is of animal origin (constituted by fibrinogen extracted from buffalos through the cryoprecipitation technique), contains elevated fibrinogen concentrations, permits good growth of cells in a new biomaterial, and poses no risk of transmitting infectious diseases by means of human blood. Although both sealants (autologous and heterologous) are natural, biodegradable, bio-absorbent, non-toxic and non-immunogenic, future comparative studies using human stem cells should be carried out to clarify these points.

\section{Competing interests}

The author declares that there are no competing interests.

Received: 4 July 2014 Accepted: 11 July 2014

Published: 18 July 2014

\section{References}

1. Thomazini-Santos IA, Giannini MJSM, Toscano E, Machado PEA, Lima CRG, Barraviera B: The evaluation of clotting time in bovine thrombin, reptilase ${ }^{\oplus}$, and thrombin-like fraction of Crotalus durissus terrificus venom using bovine, equine, ovine bubaline and human crioprecipitates. J Venom Anim Toxins 1998, 4(2):120-136. http://www.scielo.br/scielo.php?script=sci arttext\&pid=S0104-79301998000200004\&lng=en\&nrm=iso\&tlng=en.

2. Thomazini-Santos IA, Barraviera SRCS, Mendes-Giannini MJS, Barraviera B: Surgical adhesives. J Venom Anim Toxins 2001, 7(2):159-171. http://www. scielo.br/scielo.php?script=sci_arttext\&pid=\$0104-79302001000200002

3. Barros LC, Soares AM, Costa FL, Rodrigues VM, Fuly AL, Giglio JR, Gallacci M, Thomazini-Santos IA, Barraviera SRCS, Barraviera B, Ferreira RS Jr: Biochemical and biological evaluation of gyroxin isolated from Crotalus durissus terrificus venom. J Venom Anim Toxins ind Trop Dis 2011, 17(1):23-33. http://www.scielo. br/scielo.php?.pid=S1678-91992011000100004\&script=sci_arttext.

4. Barros LC, Ferreira RS Jr, Barraviera SRCS, Stolf HO, Thomazini-Santos IA Mendes-Giannini MJS, Toscano E, Barraviera B: A new fibrin sealant from Crotalus durissus terrificus venom: applications in medicine. J Toxicol Environ Health B Crit Rev 2009, 12(8):553-571. http://www.tandfonline.com/ doi/abs/10.1080/10937400903442514?url_ver=Z39.88-2003\&rff_id=ori:rid: crossref.org\&rfr_dat=cr_pub\%3Dpubmed\&\#.U7Rg_Kg_Ppw.

5. Barbizan R, Castro MV, Rodrigues AC, Barraviera B, Ferreira RS Jr, Oliveira ALR: Motor recovery and synaptic preservation after ventral root avulsion and repair with a fibrin sealant derived from snake venom. PLOS ONE 2013, 8(5):e63260. doi:10.1371/journal.pone.0063260.

6. Stolf $\mathrm{HO}$ : The use of fibrin adhesive derived from snake venom and the evaluation of skin grafting using skin from the patients nasolabial fold. J Venom Anim Toxins 1999, 5(2):227. http://www.scielo.br/scielo.php? script=sci_arttext\&pid=S0104-7930199900020001 1\&lng=en\&nrm=iso\&tlng=en.

7. Barbosa MDS, Greghi SLA, Passanezi E: Fibrin adhesive derived from snake venom in periodontal surgery. J Periodontol 2007, 78(10):2026-2031. http://www.joponline.org/doi/abs/10.1902/jop.2007.070005.

8. Barbosa MDS, Stipp AC, Passanezi E, Greghi LA: Fibrin adhesive derived from snake venom in periodontal surgery: histological analysis. J Appl Oral Sci 2008, 16(5):310-315.

9. Chiquito GCM: Comparison between suture and fibrin adhesive derived from snake venom for fixation of connective tissue graft in correction of marginal tissue recession. J Venom Anim Toxins incl Trop Dis 2007, 13(2):559. http://www.scielo.br/scielo.php?script=sci_arttext\&pid=S167891992007000200014

10. Gatti MAN, Vieira LM, Barraviera B, Barraviera SRCS: Treatment of venous ulcers with fibrin sealant derived from snake venom. J Venom Anim Toxins incl Trop Dis 2011, 17(2):226-229. http://www.scielo.br/scielo.php? pid=S1678-91992011000200015\&script=sci_arttext.

11. Gasparotto VPO, Landim-Alvarenga FC, Oliveira AL, Simões GF, Lima-Neto JF, Barraviera B, Ferreira RS Jr: A new fibrin sealant as a three-dimensional scaffold candidate for mesenchymal stem cells. Stem Cell Res Ther 2014, 5(3):78. http://stemcellres.com/content/5/3/78.
12. de la Puente P, Ludeña D: Cell culture in autologous fibrin scaffolds for applications in tissue engineering. Exp Cell Res 2014, 322(1):1-11.

13. de la Puente P, Ludeña D, Fernández A, Aranda JL, Varela G, Iglesias J: Autologous fibrin scaffolds cultured dermal fibroblasts and enriched with encapsulated bFGF for tissue engineering. J Biomed Mater Res A 2011, 99(4):648-654

14. de la Puente P, Ludeña D, López M, Ramos J, Iglesias J: Differentiation within autologous fibrin scaffolds of porcine dermal cells with the mesenchymal stem cell phenotype. Cell Res 2013, 319(3):144-152.

doi:10.1186/1678-9199-20-31

Cite this article as: Seabra Ferreira: Autologous or heterologous fibrin sealant scaffold: which is the better choice? Journal of Venomous Animals and Toxins including Tropical Diseases 2014 20:31.

\section{Submit your next manuscript to BioMed Central and take full advantage of:}

- Convenient online submission

- Thorough peer review

- No space constraints or color figure charges

- Immediate publication on acceptance

- Inclusion in PubMed, CAS, Scopus and Google Scholar

- Research which is freely available for redistribution 